\title{
Internal migration of physicians who graduated in Brazil between 1980 and 2014
}

\author{
Mario Cesar Scheffer ${ }^{1 \dagger}$, Alex Jones Flores Cassenote ${ }^{1 * \dagger}$, Aline Gil Alves Guilloux ${ }^{1}$ and Mario Roberto Dal Poz ${ }^{2}$
}

\begin{abstract}
Background: The internal migration of physicians from one place to another in the same country can unbalance the supply and distribution of these professionals in national health systems. In addition to economic, social and demographic issues, there are individual and professional factors associated with a physician's decision to migrate. In Brazil, there is an ongoing debate as to whether opening medicine programmes in the interior of the country can induce physicians to stay in these locations. This article examines the migration of physicians in Brazil based on the location of the medical schools from which they graduated.

Methods: A cross-sectional design based on secondary data of 275,801 physicians registered in the Regional Councils of Medicine (Conselhos Regionais de Medicina_CRMs) who graduated between 1980 and 2014. The evaluated outcome was migration, which was defined as moving away from the state where they completed the medicine programme to another state where they currently work or live.

Results: $57.3 \%$ of the physicians in the study migrated. The probability of migration ratio was greater in small grouped municipalities and lower in state capitals. 93.4\% of the physicians who trained in schools located in cities with less than 100,000 inhabitants migrated. Fewer women (54.2\%) migrated than men (60.0\%). More than half of the physicians who graduated between 1980 and 2014 are in federative units different from the unit in which they graduated. Individual factors, such as age, gender, time of graduation and specialty, vary between the physicians who did or did not migrate.

Conclusions: The probability of migration ratio was greater in small municipalities of the Southeast region and strong in the states of Tocantins, Acre and Santa Catarina. New studies are recommended to deepen understanding of the factors related to the internal migration and non-migration of physicians to improve human resource for health policies.
\end{abstract}

Keywords: Human resources for health, Distribution of physicians, Medical schools, Internal migration, Brazil

\section{Background}

The internal migration of physicians who leave a city or region of the country to establish themselves in another city or region of the same country can unbalance the distribution of these professionals in the national territories [1]. Relatively few studies on the various forms of internal migration of physicians and other health professionals are available in the international literature.

Studies on the mobility of physicians between countries identified a convergence of individual and professional

\footnotetext{
* Correspondence: cassenote@usp.br

${ }^{\dagger}$ Equal contributors

${ }^{1}$ Preventive Medicine Department, Medical School of University of São Paulo,

São Paulo, Brazil

Full list of author information is available at the end of the article
}

motivations as well as policy, economic, social and demographic issues [2-4]. Similar to the determinants of the mobility of skilled workers in general [5], physicians most commonly migrate from places with worse living and working conditions and with few opportunities for professional development. The attractiveness of specialized education centres, career prospects [6,7], better pay [8,9] and age [10] plays a relevant role in the decision of physicians to migrate. For instance, young physicians are more inclined to change cities or countries.

In Brazil, recent policies have focused on the number, supply, demand, distribution and training of physicians. Since 2013 with the institution of the More Doctors law [11], new training programmes have opened with expanded

(C) The Author(s). 2018 Open Access This article is distributed under the terms of the Creative Commons Attribution 4.0 International License (http://creativecommons.org/licenses/by/4.0/), which permits unrestricted use, distribution, and 
graduate vacancies in medicine, expanded medical residency programs and the admission of foreign and Brazilian physicians to practice in underserved municipalities and regions.

The "interiorization of medical training" is the decentralization of medical education resources to cities and regions where there are no or few medical schools are considered a possible inducing factor for physicians to stay in these localities [12]. There are no studies in Brazil that support this relationship, although physicians tend to remain in the cities where they conclude their medical residency [13] and these programmes are more concentrated in the South and Southeast regions of Brazil [14].

The objective of the present study is to evaluate the profile and distribution of physicians trained in Brazil between 1980 and 2014. We considered the federative units and the cities where the professionals graduated and where they currently work or reside to contribute to the understanding of the internal migration of physicians in the country.

\section{Methods}

This was cross-sectional study using secondary data from the Medical Demographics in Brazil [15]. This survey is the census that includes administrative records from: Regional Medicine Councils (Conselhos Regionais de Medicina-CRMs); National Residency Commission (Comissão Nacional de Residência-CNRM) of the Brazilian Ministry of Education (Ministério da EducaçãoMEC); and the Brazilian Medical Association (Associação Médica Brasileira-AMB).

The CRMs are responsible for registration and inspection of physicians and their professional activity. All the active physicians in Brazil must be registered in a medical council; there are 27 medical councils, one in each Brazilian Federal Unit, which together integrated the Federal Medicine Council's (Conselho Federal de Medicina-CFM) database.

All physicians registered in the CRMs who completed a degree in medicine between 1980 and 2014 were included in the study. The analysed time interval, which encompassed a significant contingent of graduated and enrolled physicians, included public or private degree programmes in various locations.

The initial database was composed of 388,203 physicians, of which $20 \%(77,569)$ did not match the temporal inclusion criteria. Of the 310,634 physicians considered, those with absent or incomplete information concerning current address or graduating school place were excluded, which led to the exclusion of $12.2 \%$ of the physicians $(34,828)$. The final database included 275,801 physicians that make up the universe of physicians who graduated in Brazil between 1980 and 2014 (Table 1).
Table 1 Physicians who graduated in Brazil between 1980 and 2014 according to the location of the graduating school in the federative units

\begin{tabular}{|c|c|c|}
\hline Federative units & Number & Percent \\
\hline São Paulo & 55874 & 20.26 \\
\hline Rio De Janeiro & 50480 & 18.30 \\
\hline Minas Gerais & 39065 & 14.16 \\
\hline Rio Grande do Sul & 24603 & 8.92 \\
\hline Parana & 13987 & 5.07 \\
\hline Bahia & 11528 & 4.18 \\
\hline Pernambuco & 9934 & 3.60 \\
\hline Pará & 7704 & 2.79 \\
\hline Espírito Santo & 7550 & 2.74 \\
\hline Ceará & 7238 & 2.62 \\
\hline Santa Catarina & 6959 & 2.52 \\
\hline Paraiba & 6237 & 2.26 \\
\hline Alagoas & 4359 & 1.58 \\
\hline Goiás & 3850 & 1.40 \\
\hline Amazonas & 3521 & 1.28 \\
\hline Rio Grande Do Norte & 3317 & 1.20 \\
\hline Federal District & 3151 & 1.14 \\
\hline Maranhão & 3085 & 1.12 \\
\hline Piauí & 2883 & 1.05 \\
\hline Mato Grosso Do Sul & 2737 & 0.99 \\
\hline Sergipe & 2291 & 0.83 \\
\hline Mato Grosso & 2177 & 0.79 \\
\hline Tocantins & 1804 & 0.65 \\
\hline Rondônia & 908 & 0.33 \\
\hline Roraima & 318 & 0.12 \\
\hline Acre & 241 & 0.09 \\
\hline Amapá & 0 & 0.0 \\
\hline Total & 275801 & 100.00 \\
\hline
\end{tabular}

The physicians' places of graduation (medical school headquarter city), the dates of the first records of the physicians in the CRM (primary enrolment) and the current addresses provided by the physicians to the CRM, which corresponded to a residence and/or work address, were considered.

The evaluated primary outcome of interest was migration. The binary variable (did not migrate/migrated) was defined as a move from one state (state of the school where the physician completed the medical degree) to another state (current living or working location). The qualitative nominal and ordinal variables were evaluated as factors and referred to the characteristics of the physicians (age, gender, date of graduation, and specialty) and the medical programmes (geographical location and public or private institution). 
The variable "type of municipality of the medical school" was stratified into three levels based on the 2010 census conducted by the Brazilian Institute of Geography and Statistics $[15,16]$ according to the population strata as follows: (1) capitals, (2) large interior municipalities (LM interior) with 100,000 or more inhabitants and (3) small interior municipalities (SM interior) with less than 100,000 inhabitants.

The migration according to the type of municipality of the medical school was analysed using a probability migration ratio (PMR) like indicator obtained from the ratio between the probability of the physician migrating following graduation from a school located in the capitals (reference category) divided by the probability of the physician migrating following graduation from a school located in the interior (LM interior and SM interior).

The Statistical Package for the Social Sciences (SPSS) 20 for Windows (International Business Machines Corp., Armonk, NY, USA) was used for the analysis. The map was generated with the aid of QGIS Geographic Information
System version 2.4.0-Chugiak (QGIS Development Team 2016. Open Source Geospatial Foundation Project: http:// qgis.org/en/site/).

This study was approved by the Ethics in Research Committee of the Medical School of the University of São Paulo (Universidade de São Paulo) (Opinion n. 797,424, 09/03/2014).

\section{Results}

Among the 275,801 total physicians considered, 157,998 $(57.3 \%)$ migrated (i.e., were living and/or working in a different state than the state where the medical school from which they graduated was located at the time of the study) (Table 1 and Fig. 1).

From the total physicians analysed, $52.9 \%$ were male, $22.8 \%$ were below 35 years of age, $22.5 \%$ had graduated at least 5 years ago and $60 \%$ had completed their specialization or medical residence in one of the 53 recognized medical specialties. Most of the physicians

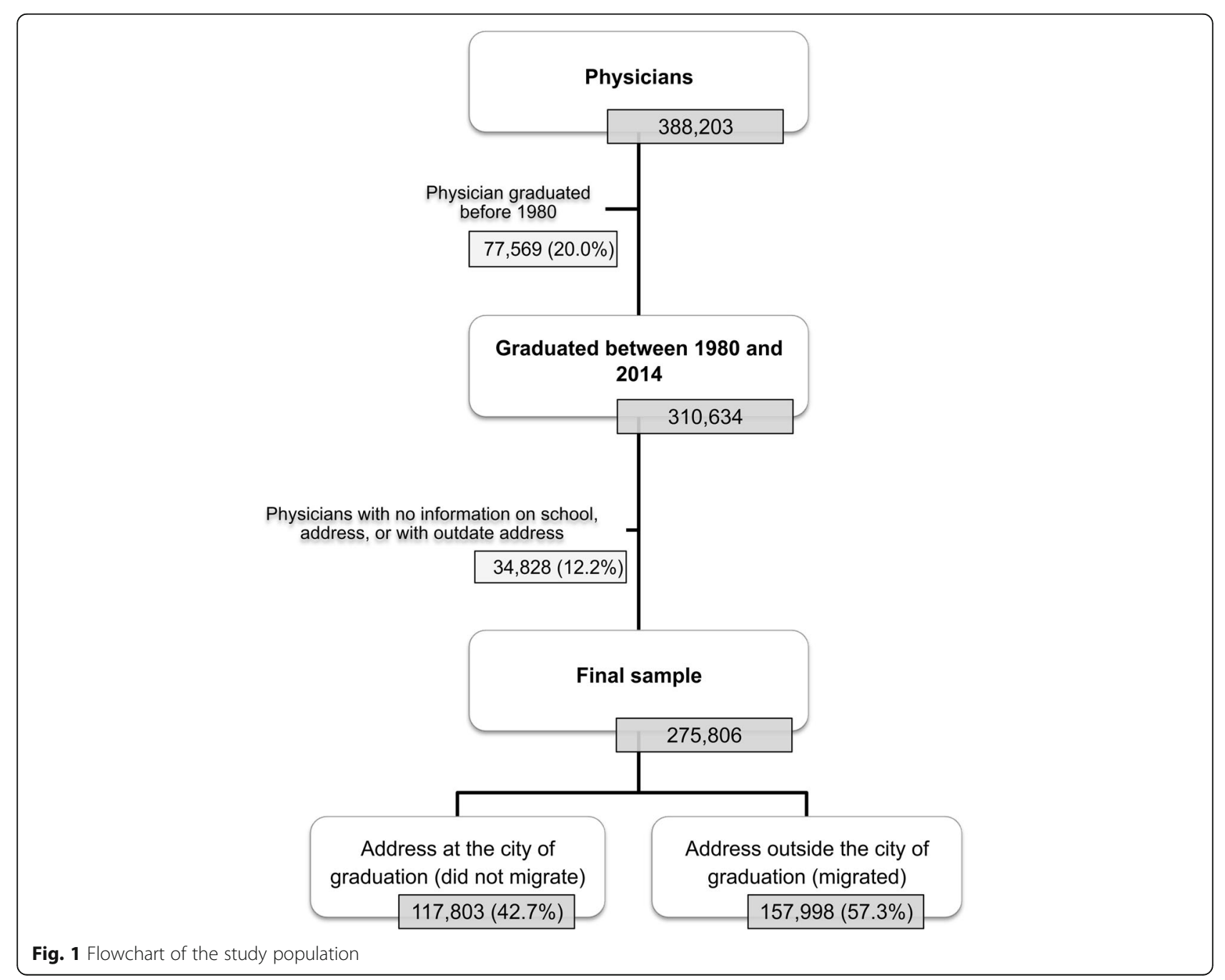


graduated from public schools (57.9\%) located in the Southeast region (55.5\%) and the state capitals (56.1\%).

From 1980 to 2014, more than half of the Brazilian physicians $(52.7 \%)$ graduated from schools located in the following three states: São Paulo (55,874 physicians or $20.2 \%$ of the total), Rio de Janeiro $(50,480$ or $18.3 \%)$ and Minas Gerais $(39,065$ or $14.1 \%)$. The states with the fewest graduated physicians were Acre (241 or $0.09 \%$ ), Roraima (318 or $0.12 \%$ ) and Rondônia (908 or $0.33 \%$ ). The state of Amapá did not have any graduated physicians registered because it did not have a medical programme during the analysed period (Table 1).

A total of $60.7 \%$ of the physicians older than 35 to 40 years of age migrated. In the age range below or equal to 30 years, $52.0 \%$ migrated (Table 2 ). The women migrated less than the men (54.2 and $60.0 \%$, respectively). A greater proportion of physicians who graduated 10 to 15 years before the study migrated $(60.1 \% \mathrm{mi}$ grated) compared to the other groups stratified by the time since graduation. Additionally, more physicians without a specialization migrated (59.7\%) compared with the specialists (55.7\%) and physicians from private medical schools (67.8\%) compared with the public medical schools (49.7).

Migration was also analysed according to the location of the graduate schools based on the municipality size and country region. In all regions, PMR was greater in small municipalities and lower in the capitals. Compared to the capitals, PMR of physicians who graduated from schools located in the group of small municipalities was 9.7-fold higher (Table 3).

A total of $93.4 \%$ of the physicians who graduated from schools located in municipalities with less than 100,000 inhabitants migrated (Table 2). The Southeast region had the largest absolute and relative contingent of physicians who graduated from small municipalities, and $93.8 \%$ of these physicians migrated (Table 3 ). Regarding the nature of the schools, physicians who graduated from private schools migrated more often $(67.8 \%)$ than physicians who graduated from public schools (49.7\%), although in the physicians analysed the physicians who graduated from private schools represented $42.1 \%$ of the total.

Among the Brazilian states, the largest migration ratios were observed in Tocantins (85.3\%), Santa Catarina (70.5\%), Acre (60.6\%) and Rio Grande do Sul (61.9\%), whereas Alagoas (25.3\%), Ceará (31.5\%), Amazonas (33. $5 \%)$ and Piauí (34.8\%) had the smallest migration percentages (Fig. 2).

Table 4 shows the physician population rate (PPR) and the percent of graduated, migrated and immigrated physicians according Brazilian states and populational stratum. In this table, it is possible to evaluate some phenomena: (I) in almost all situations, small municipalities (SM interior) lost more than $85 \%$ of medical graduates;
(II) from the 16 municipalities (LG interior) that had the potential to train physicians, only 2 of them lost less than $65 \%$ of medical graduates; (III) from the 26 capital cities, only 6 lost more than $65 \%$ of medical graduates; and (IV) the capital of São Paulo state receives twice as many physicians as it loses.

There is a high migratory flow of physician from capitals, LG interior and LM interior for the capitals of the Brazilian states, with special focus on the Southeast region or to the capital of the same region of the medical school graduation: $26.1 \%$ of the physician from capitals of the North region migrated to capital cities of the Southeast region; $36.1 \%$ of the physician from LM interior of the Southeast region migrated to some capitals of the same region. Other similar examples can be seen in Additional file 1: Table S1.

\section{Discussion}

In December of 2017, Brazil had 447.321 [17] physicians and a population of 207,660,929 [18] inhabitants, which corresponded to a density of 2.17 physicians per 1000 inhabitants. The distribution of these professionals in the national territory was unequal [18], with the North (1.09 physicians per 1000 inhabitants) and Northeast (1. 3) regions below the national ratio. In the seven Northern states, the ratio varied from 0.91 to 1.51 . In the Northeast, the state of Maranhão had the lowest ratio of the country, with 0.79 physicians per 1000 inhabitants. The Southeast, with 2.75 physicians per 1000 inhabitants, the South, with 2.18, and the Central-West region, with 2.20 , were above the national average.

In 2014, there were 241 active medical schools in Brazil, which together offered approximately 20,340 vacancies and were located mostly in the Southeast (99 schools, 41. $0 \%$ ) and Northeast (61 schools, 25.3\%). Among the states, São Paulo (41 schools, 17\%), Minas Gerais (34 schools, 14. $1 \%)$, Rio de Janeiro (17 schools, 7.0\%), Paraná (15 schools, 6.2\%) and Rio Grande do Sul (15 schools, 6.2\%) had the most medical schools. Currently, there are medical schools in all 27 federative units [17].

In the present study, 176 schools that trained physicians in Brazil between the years considered (1980 and 2014) were headquartered in 103 different municipalities. Of these, 25 were located in the state capitals and the Federal District, 63 were in large interior municipalities and 14 were in small interior municipalities.

Notably, among the 14,382 physicians who graduated from medical schools located in small interior municipalities (those with less than 100,000 inhabitants), the large majority (93.4\%) did not stay at these locations. Most physicians who graduated from private medical schools also migrated (67.8\%) regardless of the size of the municipality where the school was located. 
Table 2 Physicians who graduated between 1980 and 2014 who migrated and did not migrate according to gender, time since graduation, specialization and characteristics of the graduating schools

\begin{tabular}{|c|c|c|c|c|c|}
\hline & Did not migrate & Percent & Migrated & Percent & Total \\
\hline \multicolumn{6}{|c|}{ Physicians' characteristics } \\
\hline \multicolumn{6}{|l|}{ Age } \\
\hline$\leq 30$ years & 25096 & 48.0 & 27201 & 52.0 & 52297 \\
\hline $30-35$ years & 22303 & 41.2 & 31805 & 58.8 & 54108 \\
\hline $35-40$ years & 16521 & 39.3 & 25490 & 60.7 & 42011 \\
\hline $40-45$ years & 13751 & 42.2 & 18870 & 57.8 & 32621 \\
\hline $45-50$ years & 13098 & 42.9 & 17419 & 57.1 & 30517 \\
\hline $50-55$ years & 13497 & 43.6 & 17439 & 56.4 & 30936 \\
\hline $55-60$ years & 10838 & 41.7 & 15162 & 58.3 & 26000 \\
\hline $60-65$ years & 2014 & 36.1 & 3572 & 63.9 & 5586 \\
\hline $65-70$ years & 407 & 37.8 & 669 & 62.2 & 1076 \\
\hline$\geq 70$ years & 273 & 42.5 & 369 & 57.5 & 642 \\
\hline \multicolumn{6}{|l|}{ Gender } \\
\hline Female & 59529 & 45.8 & 70421 & 54.2 & 129950 \\
\hline Male & 58274 & 40.0 & 87577 & 60.0 & 145851 \\
\hline \multicolumn{6}{|c|}{ Time since graduation } \\
\hline$\leq 5$ years & 29591 & 47.8 & 32327 & 52.2 & 61918 \\
\hline $5-10$ years & 19601 & 39.2 & 30392 & 60.8 & 49993 \\
\hline $10-15$ years & 14895 & 39.0 & 23264 & 61.0 & 38159 \\
\hline $15-20$ years & 13627 & 42.3 & 18558 & 57.7 & 32185 \\
\hline $20-25$ years & 13265 & 43.2 & 17425 & 56.8 & 30690 \\
\hline $25-30$ years & 13428 & 43.4 & 17523 & 56.6 & 30951 \\
\hline $30-35$ years & 11990 & 41.0 & 17258 & 59.0 & 29248 \\
\hline$\geq 35$ years & 1405 & 52.9 & 1248 & 47.1 & 2653 \\
\hline \multicolumn{6}{|l|}{ Specialist } \\
\hline No & 43531 & 40.3 & 64469 & 59.7 & 108000 \\
\hline Yes & 74272 & 44.3 & 93529 & 55.7 & 167801 \\
\hline Total & 117803 & 42.7 & 157998 & 57.3 & 275801 \\
\hline \multicolumn{6}{|c|}{ School characteristics } \\
\hline \multicolumn{6}{|l|}{ Greater region } \\
\hline North & 6903 & 47.6 & 7593 & 52.4 & 14496 \\
\hline Northeast & 30676 & 60.3 & 20196 & 39.7 & 50872 \\
\hline Southeast & 54591 & 35.7 & 98378 & 64.3 & 152969 \\
\hline South & 18704 & 41.1 & 26845 & 58.9 & 45549 \\
\hline Central-West & 6929 & 58.2 & 4986 & 41.8 & 11915 \\
\hline \multicolumn{6}{|l|}{ Municipality } \\
\hline Capital & 93034 & 60.2 & 61624 & 39.8 & 154658 \\
\hline$L M$ interior $^{a}$ & 23822 & 22.3 & 82939 & 77.7 & 106761 \\
\hline SM interior ${ }^{b}$ & 947 & 6.6 & 13435 & 93.4 & 14382 \\
\hline \multicolumn{6}{|c|}{ Legal nature of school } \\
\hline Public & 80356 & 50.3 & 79339 & 49.7 & 159695 \\
\hline Private & 37438 & 32.2 & 78653 & 67.8 & 116091 \\
\hline No information & 9 & 60.0 & 6 & 40.0 & 15 \\
\hline Total & 117803 & 42.7 & 157998 & 57.3 & 275801 \\
\hline
\end{tabular}


Table 3 Physicians who graduated in Brazil between 1980 and 2014 who migrated and did not migrate according to the location of the graduating school in the Greater Regions and in municipalities grouped by size

\begin{tabular}{|c|c|c|c|c|c|c|}
\hline & Did not migrate & Percent & Migrated & Percent & Total & $\overline{P M R}$ \\
\hline \multicolumn{7}{|l|}{ North } \\
\hline Capital & 6628 & 52.4 & 6027 & 47.6 & 12655 & 1.00 \\
\hline LM interior & 167 & 17.5 & 789 & 82.5 & 956 & 3.00 \\
\hline SM interior & 108 & 12.2 & 777 & 87.8 & 885 & 4.29 \\
\hline Total & 6903 & 47.6 & 7593 & 52.4 & 14496 & - \\
\hline \multicolumn{7}{|l|}{ Northeast } \\
\hline Capital & 29635 & 62.9 & 17461 & 37.1 & 47096 & 1.00 \\
\hline LM interior & 1041 & 27.6 & 2735 & 72.4 & 3776 & 2.28 \\
\hline SM interior & 0 & 0.0 & 0 & 0.0 & 0 & - \\
\hline Total & 30676 & 60.3 & 20196 & 39.7 & 50872 & - \\
\hline \multicolumn{7}{|l|}{ Southeast } \\
\hline Capital & 36723 & 60.3 & 24218 & 39.7 & 60941 & 1.00 \\
\hline LM interior & 17057 & 21.6 & 61921 & 78.4 & 78978 & 2.79 \\
\hline SM interior & 811 & 6.2 & 12239 & 93.8 & 13050 & 9.70 \\
\hline Total & 54591 & 35.7 & 98378 & 64.3 & 152969 & - \\
\hline \multicolumn{7}{|l|}{ South } \\
\hline Capital & 13200 & 58.1 & 9505 & 41.9 & 22705 & 1.00 \\
\hline LM interior & 5476 & 24.2 & 17164 & 75.8 & 22640 & 2.40 \\
\hline SM interior & 28 & 13.7 & 176 & 86.3 & 204 & 4.24 \\
\hline Total & 18704 & 41.1 & 26845 & 58.9 & 45549 & - \\
\hline \multicolumn{7}{|l|}{ Central-West } \\
\hline Capital & 6848 & 60.8 & 4413 & 39.2 & 11261 & 1.00 \\
\hline LM interior & 81 & 19.7 & 330 & 80.3 & 411 & 3.09 \\
\hline SM interior & 0 & 0.0 & 243 & 100.0 & 243 & - \\
\hline Total & 6929 & 58.2 & 4986 & 41.8 & 11915 & - \\
\hline Total & 117803 & 42.7 & 157998 & 57.3 & 275801 & - \\
\hline
\end{tabular}

LM interior-interior large municipalities $\geq 100000$ inhabitants; SM interior-interior small municipalities $<100000$ inhabitants

PMR probability migration ratio

Given the trend towards the interiorization and privatization of medical education in Brazil [19], the results of this study allow us to draw preliminary conclusions about the relationship between the location and nature of the school and the non-migration of physicians.

If adopted as an isolated measure, the opening of new, mostly private programmes in municipalities in the interior of the country in regions with a scarcity or a lower density of physicians per inhabitant may not directly affect the permanence of the graduated physicians in these locations. In this sense, the analysis has limitations because the study included a low number of physicians who graduated in small municipalities in the Northeast, North, Central-West and South regions because the internalization of medical schools is a recent phenomenon in Brazil.

The less-intense migration of women compared to men corroborates the literature, which indicates that the female gender is less prone to territorial relocation [20]. Thus, the feminization of medicine in Brazil [21] takes on increased relevance in the different aspects of the observed migration process, with a possible future positive effect on the non-migration of physicians.

The state capitals retained more physicians who graduated there. Although they had a smaller proportion than the capitals, the large cities of the country seemed to be more attractive than small cities to the physicians who graduated in these locations, which experienced a mass migration of physicians who graduated from their schools.

In Brazil, it was observed that the 39 cities with more than 500,000 inhabitants concentrated $30 \%$ of the population and $60 \%$ of the physicians, which directly affected the low physician/inhabitant ratio in the small municipalities. For example, in locations with 5000 to 10,000 inhabitants, the ratio is 0.28 physicians per 1000 residents. In municipalities with between 10,000 and 20,000 


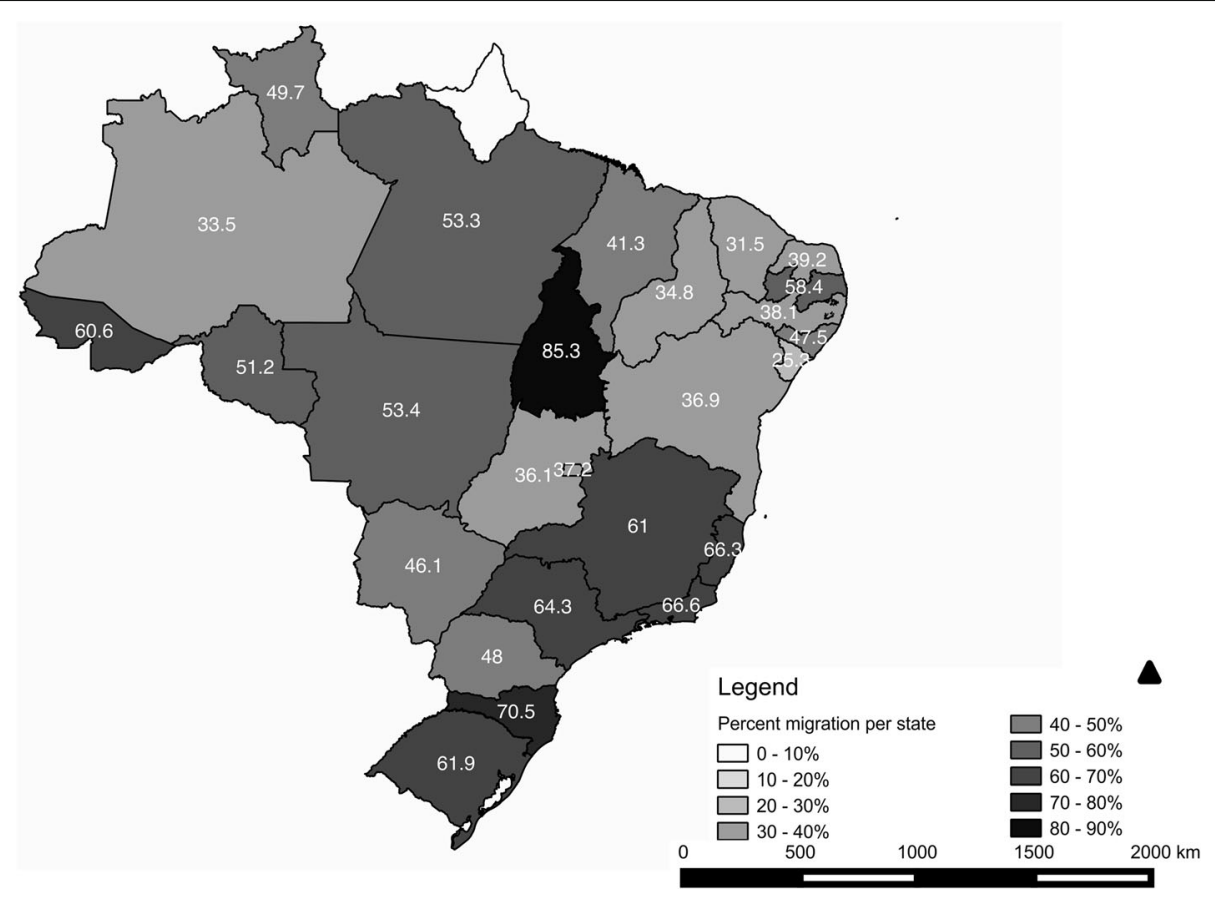

Fig. 2 Percentage of trained physicians who migrated to another state per federative unit

residents, the ratio is 0.36 , whereas in municipalities with between 20,000 and 50,000 residents, the ratio is 0 . 64 physicians per 1000 inhabitants [15].

The results presented in Table 4 and in Additional file 1: Table S1 suggest that there is a high migratory flow between the capitals of the Brazilian states, especially with high influence of the state capitals from Southeast region; this region concentrates the largest number of medical residency programs in Brazil [14]. The few municipalities with less than 100,000 inhabitants, with the potential to train physicians, presented little retention capacity, losing their graduates to other regions. This situation has contributed to maintaining the low average per capita medical rate in these localities.

In this study, we also observed that there is a higher migration rate for physicians coming from private schools. This result may raise a warning about the new interiorization policies of medical schools in Brazil, a process that has resulted in an increase in the opening of private schools in the interiors of the states; one of the arguments used by the managers of this policy was that there could be retention of doctors in the host cities of medical schools and their surroundings.

In a systematic review realized by Willis-Shattuck et al. [22] to examine motivating factors that would reduce medical migration both within and across countries, the following factors were listed: financial incentives, career development, continuing education, hospital infrastructure, resource availability, hospital management and personal recognition or appreciation. A more recent systematic review identified similar variables with a high degree of similarity between selected studies; however, workload and autonomy seem to be specific to physicians' choice of workplace between the public and private sectors [23].

A study that analysed geographical mobility of general practitioners in rural Australia found that in small towns of $<5000$ residents had the highest risk of leaving rural practice. Mobility rates were significantly higher for GPs who had worked in a location for under 3 years and those working as either contracted or salaried employees, and somewhat higher for international medical graduates [24].

Mobility of US Rural Primary Care Physicians During 2000-2014 was analysed. The researchers noted that county-level physician mobility was higher for counties that lacked a hospital (absolute increase $=5.7 \%$ ), had a smaller population size, and had lower primary care physician supply, but area level economic and demographic factors had little impact. Their conclusion was that outcomes were notably poorer in the most remote locations and those already having poorer physician supply and professional support [25].

This study may be considered a starting point for the required in-depth analysis of migratory patterns of physicians in Brazil. By using the database of administrative and professional records, it was possible to characterize the variables associated with the medical school and with the physicians who did or did not migrate.

Due to the sole focus on the comparison of the current address and graduation location, the present study did not 
Table 4 Training and migration/immigration of physician in Brazilian municipalities according to states and population strata between 1980 and 2014

\begin{tabular}{|c|c|c|c|c|c|c|c|}
\hline State & Stratum & Population & Physician in 2014 & $\mathrm{PPR}^{\mathrm{a}}$ & \%graduated & \%migrated & \%immigrated \\
\hline \multirow[t]{3}{*}{ Rondônia } & Capital & 484992 & 1283 & 2.65 & $0.29 \%$ & $49.0 \%$ & $54.6 \%$ \\
\hline & LG interior & 229295 & 334 & 1.46 & $0.00 \%$ & $0.00 \%$ & $100.0 \%$ \\
\hline & SM interior & 1013927 & 670 & 0.66 & $0.04 \%$ & $68.3 \%$ & $91.8 \%$ \\
\hline \multirow[t]{3}{*}{ Acre } & Capital & 357194 & 726 & 2.03 & $0.09 \%$ & $60.6 \%$ & $74.7 \%$ \\
\hline & LG interior & - & - & - & - & - & - \\
\hline & SM interior & 419269 & 175 & 0.42 & $0.00 \%$ & $0.00 \%$ & $100.0 \%$ \\
\hline \multirow[t]{3}{*}{ Amazonas } & Capital & 1982177 & 4123 & 2.08 & $1.28 \%$ & $33.5 \%$ & $20.7 \%$ \\
\hline & LG interior & 109225 & 31 & 0.28 & $0.00 \%$ & $0.00 \%$ & $100.0 \%$ \\
\hline & SM interior & 1716519 & 212 & 0.12 & $0.00 \%$ & $0.00 \%$ & $100.0 \%$ \\
\hline \multirow[t]{3}{*}{ Roraima } & Capital & 308996 & 657 & 2.13 & $0.12 \%$ & $49.7 \%$ & $63.9 \%$ \\
\hline & LG interior & - & - & - & - & - & - \\
\hline & SM interior & 179076 & 20 & 0.11 & $0.00 \%$ & $0.00 \%$ & $100.0 \%$ \\
\hline \multirow[t]{3}{*}{ Para } & Capital & 1425922 & 5333 & 3.74 & $2.79 \%$ & $53.3 \%$ & $5.1 \%$ \\
\hline & LG interior & 2435197 & 1341 & 0.55 & $0.00 \%$ & $0.00 \%$ & $100.0 \%$ \\
\hline & SM interior & 4138610 & 617 & 0.15 & $0.00 \%$ & $0.00 \%$ & $100.0 \%$ \\
\hline \multirow[t]{3}{*}{ Amapa } & Capital & 437256 & 621 & 1.42 & $0.00 \%$ & $0.00 \%$ & $100.0 \%$ \\
\hline & LG interior & 108897 & 29 & 0.27 & $0.00 \%$ & $0.00 \%$ & $100.0 \%$ \\
\hline & SM interior & 188843 & 23 & 0.12 & $0.00 \%$ & $0.00 \%$ & $100.0 \%$ \\
\hline \multirow[t]{3}{*}{ Tocantins } & Capital & 257904 & 840 & 3.26 & $0.02 \%$ & $64.2 \%$ & $96.1 \%$ \\
\hline & LG interior & 164093 & 548 & 3.34 & $0.35 \%$ & $82.5 \%$ & $53.1 \%$ \\
\hline & SM interior & 1056167 & 762 & 0.72 & $0.28 \%$ & $90.4 \%$ & $83.3 \%$ \\
\hline \multirow[t]{3}{*}{ Maranhao } & Capital & 1053922 & 3327 & 3.16 & $1.09 \%$ & $40.1 \%$ & $22.8 \%$ \\
\hline & LG interior & 1185668 & 989 & 0.83 & $0.03 \%$ & $90.5 \%$ & $98.6 \%$ \\
\hline & SM interior & 4554711 & 634 & 0.14 & $0.00 \%$ & $0.00 \%$ & $100.0 \%$ \\
\hline \multirow[t]{3}{*}{ Piaui } & Capital & 836475 & 3714 & 4.44 & $1.05 \%$ & $34.8 \%$ & $23.6 \%$ \\
\hline & LG interior & 148832 & 188 & 1.26 & $0.00 \%$ & $0.00 \%$ & $100.0 \%$ \\
\hline & SM interior & 2198859 & 675 & 0.31 & $0.00 \%$ & $0.00 \%$ & $100.0 \%$ \\
\hline \multirow[t]{3}{*}{ Ceara } & Capital & 2551806 & 8684 & 3.40 & $2.33 \%$ & $25.0 \%$ & $25.3 \%$ \\
\hline & LG interior & 1491079 & 1470 & 0.99 & $0.30 \%$ & $82.8 \%$ & $86.3 \%$ \\
\hline & SM interior & 4735691 & 1331 & 0.28 & $0.00 \%$ & $0.00 \%$ & $100.0 \%$ \\
\hline \multirow[t]{3}{*}{ RG Do Norte } & Capital & 853928 & 3808 & 4.46 & $1.16 \%$ & $38.1 \%$ & $26.4 \%$ \\
\hline & LG interior & 509728 & 747 & 1.47 & $0.04 \%$ & $70.6 \%$ & $93.9 \%$ \\
\hline & SM interior & 2010303 & 472 & 0.23 & $0.00 \%$ & $0.00 \%$ & $100.0 \%$ \\
\hline \multirow[t]{3}{*}{ Paraiba } & Capital & 769607 & 4291 & 5.58 & $1.55 \%$ & $54.6 \%$ & $19.7 \%$ \\
\hline & LG interior & 637589 & 1678 & 2.63 & $0.71 \%$ & $66.7 \%$ & $37.8 \%$ \\
\hline & SM interior & 2507225 & 799 & 0.32 & $0.00 \%$ & $0.00 \%$ & $100.0 \%$ \\
\hline \multirow[t]{3}{*}{ Pernanbuco } & Capital & 1599513 & 10360 & 6.48 & $3.51 \%$ & $37.5 \%$ & $15.4 \%$ \\
\hline & LG interior & 2872156 & 2792 & 0.97 & $0.10 \%$ & $59.8 \%$ & $93.5 \%$ \\
\hline & SM interior & 4736881 & 1034 & 0.22 & $0.00 \%$ & $0.00 \%$ & $100.0 \%$ \\
\hline \multirow[t]{3}{*}{ Alagoas } & Capital & 996733 & 3987 & 4.00 & $1.58 \%$ & $47.5 \%$ & $11.9 \%$ \\
\hline & LG interior & 227640 & 261 & 1.15 & $0.00 \%$ & $0.00 \%$ & $100.0 \%$ \\
\hline & SM interior & 2076562 & 362 & 0.17 & $0.00 \%$ & $0.00 \%$ & $100.0 \%$ \\
\hline Sergipe & Capital & 614577 & 3180 & 5.17 & $0.83 \%$ & $25.3 \%$ & $27.5 \%$ \\
\hline
\end{tabular}


Table 4 Training and migration/immigration of physician in Brazilian municipalities according to states and population strata between 1980 and 2014 (Continued)

\begin{tabular}{|c|c|c|c|c|c|c|c|}
\hline State & Stratum & Population & Physician in 2014 & $\mathrm{PPR}^{a}$ & \%graduated & \%migrated & \%immigrated \\
\hline & LG interior & 272877 & 40 & 0.15 & $0.00 \%$ & $0.00 \%$ & $100.0 \%$ \\
\hline & SM interior & 1308208 & 157 & 0.12 & $0.00 \%$ & $0.00 \%$ & $100.0 \%$ \\
\hline \multirow[t]{3}{*}{ Bahia } & Capital & 2883682 & 11582 & 4.02 & $3.98 \%$ & $34.7 \%$ & $16.4 \%$ \\
\hline & LG interior & 3137964 & 4428 & 1.41 & $0.20 \%$ & $81.4 \%$ & $96.6 \%$ \\
\hline & SM interior & 9022491 & 2641 & 0.29 & $0.00 \%$ & $0.00 \%$ & $100.0 \%$ \\
\hline \multirow[t]{3}{*}{ Minas Gerais } & Capital & 2479165 & 16739 & 6.75 & $5.11 \%$ & $35.6 \%$ & $31.7 \%$ \\
\hline & LG interior & 6608202 & 16518 & 2.50 & $7.23 \%$ & $71.8 \%$ & $54.6 \%$ \\
\hline & SM interior & 11505989 & 12194 & 1.06 & $1.83 \%$ & $89.4 \%$ & $93.7 \%$ \\
\hline \multirow[t]{3}{*}{ Esp. Santo } & Capital & 348268 & 4146 & 11.90 & $2.56 \%$ & $65.4 \%$ & $19.6 \%$ \\
\hline & LG interior & 2022488 & 3611 & 1.79 & $0.18 \%$ & $78.8 \%$ & $96.2 \%$ \\
\hline & SM interior & 1468610 & 1034 & 0.70 & $0.00 \%$ & $0.00 \%$ & $100.0 \%$ \\
\hline \multirow[t]{3}{*}{ Rio De Jan. } & Capital & 6429923 & 40378 & 6.28 & $7.42 \%$ & $37.7 \%$ & $39.2 \%$ \\
\hline & LG interior & 7860741 & 16550 & 2.11 & $7.98 \%$ & $82.6 \%$ & $60.6 \%$ \\
\hline & SM interior & 2078515 & 3035 & 1.46 & $2.90 \%$ & $96.5 \%$ & $83.8 \%$ \\
\hline \multirow[t]{3}{*}{ São Paulo } & Capital & 11821873 & 54978 & 4.65 & $7.01 \%$ & $35.5 \%$ & $65.3 \%$ \\
\hline & LG interior & 20588317 & 47241 & 2.29 & $13.25 \%$ & $79.5 \%$ & $76.5 \%$ \\
\hline & SM interior & 10950963 & 11825 & 1.08 & $0.00 \%$ & $0.00 \%$ & $100.0 \%$ \\
\hline \multirow[t]{3}{*}{ Parana } & Capital & 1848946 & 10738 & 5.81 & $3.68 \%$ & $41.4 \%$ & $26.7 \%$ \\
\hline & LG interior & 3825638 & 7283 & 1.90 & $1.39 \%$ & $65.4 \%$ & $75.3 \%$ \\
\hline & SM interior & 5322881 & 4093 & 0.77 & $0.00 \%$ & $0.00 \%$ & $100.0 \%$ \\
\hline \multirow[t]{3}{*}{ Santa Cat. } & Capital & 453285 & 3604 & 7.95 & $1.15 \%$ & $62.3 \%$ & $54.6 \%$ \\
\hline & LG interior & 2504181 & 6380 & 2.55 & $1.30 \%$ & $76.9 \%$ & $82.7 \%$ \\
\hline & SM interior & 3676788 & 3559 & 0.97 & $0.07 \%$ & $86.3 \%$ & $98.8 \%$ \\
\hline \multirow[t]{3}{*}{ RG Do Sul } & Capital & 1467816 & 13068 & 8.90 & $3.40 \%$ & $35.5 \%$ & $36.0 \%$ \\
\hline & LG interior & 3865596 & 8504 & 2.20 & $5.52 \%$ & $78.2 \%$ & $48.0 \%$ \\
\hline & SM interior & 5830631 & 5730 & 0.98 & $0.00 \%$ & $0.00 \%$ & $100.0 \%$ \\
\hline \multirow[t]{3}{*}{ MG Do Sul } & Capital & 832352 & 2900 & 3.48 & $0.86 \%$ & $40.5 \%$ & $36.2 \%$ \\
\hline & LG interior & 424478 & 967 & 2.28 & $0.13 \%$ & $82.2 \%$ & $89.1 \%$ \\
\hline & SM interior & 1330439 & 1022 & 0.77 & $0.00 \%$ & $0.00 \%$ & $100.0 \%$ \\
\hline \multirow[t]{3}{*}{ Mato Grosso } & Capital & 569830 & 2279 & 4.00 & $0.79 \%$ & $53.4 \%$ & $40.8 \%$ \\
\hline & LG interior & 594533 & 628 & 1.06 & $0.00 \%$ & $0.00 \%$ & $100.0 \%$ \\
\hline & SM interior & 2017750 & 1579 & 0.78 & $0.00 \%$ & $0.00 \%$ & $100.0 \%$ \\
\hline \multirow[t]{3}{*}{ Goias } & Capital & 1393575 & 7915 & 5.68 & $1.29 \%$ & $31.4 \%$ & $57.0 \%$ \\
\hline & LG interior & 1892869 & 1615 & 0.85 & $0.01 \%$ & $63.4 \%$ & $98.6 \%$ \\
\hline & SM interior & 3147604 & 2381 & 0.76 & $0.09 \%$ & $100.0 \%$ & $100.0 \%$ \\
\hline Dist. Federal & Capital & 2789761 & 8299 & 2.97 & $1.14 \%$ & $37.2 \%$ & $63.3 \%$ \\
\hline
\end{tabular}

LM interior-interior large municipalities $\geq 100000$ inhabitants; SM interior-interior small municipalities $<100000$ inhabitants

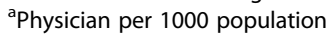

analyse the migratory flow of physicians as a whole and did not consider the effect of the birthplace on relocation. Because this study was a cross-sectional study, it was not possible to capture possible intermediate moves and destinations over time or define whether the current location of the physician was definitive. In a classic study from
1978 on the flows and stocks of nurses and physicians, Mejía [26, 27] highlighted the difficulties of defining whether a professional's migration was "permanent" or "temporary" based on secondary data.

Another limitation of the analysis is the concept of migration adopted in this study. The movement of a physician 
from one state to another may not represent a large displacement when it occurs between cities near the state border and can underestimate large displacements within the same state.

In this study, it was not possible to isolate the effect of the location of the medical school in relation to other cultural, employment, and socioeconomic factors that can influence migration.

Future studies on the subject may consider the characteristics of the place of origin (prior to obtaining the medical degree) and the current location of the professionals who migrated. For this purpose, more refined methods will be required, such as methods that use migration networks to establish possible migratory patterns.

\section{Conclusion}

More than half of the physicians who graduated between 1980 and 2014 are living and/or working in federative units different from the unit where the medical school from which they graduated was located.

The considerable and dynamic internal migration of physicians in Brazil (defined in this study as the relocation or mobility of professionals from one state to another) seems to contribute to imbalances in the distribution, supply and availability of physicians in the country, whose motives are not yet fully clear.

When compared with physicians who remained in the state in which they graduated, there was a difference in the profiles of the physicians who migrated regarding individual factors, such as age, gender, time since graduation and specialty, which could partially explain the decision to migrate.

The probability of migration ratio was greater in small municipalities of the Southeast region and in the states of Tocantins, Acre and Santa Catarina, which also experienced a more pronounced migration of physicians.

To guide adequate human resource policies in health, new studies are required that consider the socioeconomic level of the location, the establishment of services and employment and continued training opportunities among other possible factors for the non-migration of physicians.

The "push" and "pull" mechanisms that motivate the internal migration of physicians are complex and multifactorial and can have consequences that require more research. For instance, qualitative studies should be performed to examine the migration networks and flows that are able to capture the controlled turnover (i.e., the supply of jobs to physicians from the outside) to meet the needs of health services and to offset retirement and other forms of replacement and exchange of professionals. More studies are also needed on voluntary turnover, which is when the physician leaves a certain place in search of better living conditions, wages or career prospects without a previous offer.

Similarly, the motivations for temporary migration should be explored by human resources policies, which can produce benefits by aggregating value to the professional and the local health system upon the physician's return. This situation is in contrast to permanent migration, which can represent the transfer of human capital from one place to another and thus weaken the capacity of local health systems [2, 27-30].

Finally, research efforts should focus on monitoring the future movement of physicians in Brazil and other countries to identify factors related to internal migration and non-migration of these professionals and contribute to the conception, planning and assessment of public policies of human resources in health.

\section{Additional file}

Additional file 1: Table S1. Origin and destination of the physicians who graduated in Brazil between 1980 and 2014. (DOCX 33 kb)

\section{Funding}

This study takes place with the financial support Fundação Faculdade de Medicina (FFM), conselho Regional de Medicina do Estado de São Paulo (Cremesp) and Conselho Federal de Medicina (CFM), agreement (\#0075/ 2015). Alex Jones Flores Cassenote was given a PhD Student scholarship from the São Paulo Research Foundation - FAPESP (proc. 2013/18158-0).

\section{Availability of data and materials}

The datasets generated and/or analysed during the current study are not publicly available due to restriction prohibiting the authors from making the minimal data set publicity available, due to ethical issues related to participant confidentiality imposed by the Ethics Committee of the medical School of the University of São Paulo. Data from this paper are available upon request to the Ethics Committee of the Medical School of the University of São Paulo. Mailing address: 251 Dr. Arnaldo Avenue- Cerqueira César - 01246-000 - São Paulo - SP - Brazil. Phone: +55 (11) 3893-4401: Dr. Maria Aparecida Azevedo Koike FoLMueira.

\section{Authors' contributions}

MSC, AJFC and AGAG made substantial contributions to conception and design, or acquisition of data, or analysis and interpretation of data; MSC and MRDP have been involved in drafting the manuscript or revising it critically for important intellectual content; MSC, AJFC and AGAG given final approval of the version to be published. Each author should have participated sufficiently in the work to take public responsibility for appropriate portions of the content; and MSC, AJFC and AGAG agreed to be accountable for all aspects of the work in ensuring that questions related to the accuracy or integrity of any part of the work are appropriately investigated and resolved. All authors read and approved the final manuscript.

Ethics approval and consent to participate

This study was approved by the Ethics in Research Committee of the Medical School of the University of São Paulo (Universidade de São Paulo) (Decision \#. 797,424, 09/03/2014).

Competing interests

The authors declare that they have no competing interests.

\section{Publisher's Note}

Springer Nature remains neutral with regard to jurisdictional claims in published maps and institutional affiliations. 


\section{Author details}

'Preventive Medicine Department, Medical School of University of São Paulo, São Paulo, Brazil. ${ }^{2}$ Institute of Social Medicine, University of Rio de Janeiro State, Rio de Janeiro, Brazil.

Received: 6 July 2017 Accepted: 20 April 2018

Published online: 02 May 2018

\section{References}

1. World Health Organization, Poz M, Gupta N, Quain E, Soucat A. Handbook on monitoring and evaluation of human resources for health. Geneva: World Health Organization; 2009.

2. García-Pérez MA, Amaya C, Otero Á. Physicians' migration in Europe: an overview of the current situation. BMC Health Serv Res. 2007;7:201.

3. OCDE. Les Migrations Internationales dês Personnels de Santé: Améliorer La Coopération Internationalepourfaire Face à la Crise Mondiale. Paris: OCDE; 2010.

4. Wismar M, Maier CB, Glinos IA, Dussault G, Figueras J. Health professional mobility and health systems: evidence from 17 European countries. European Observer. 2011;13:1-4.

5. OECD. 2015. International Migration Outlook, 22 Sep, ISBN: 9789264243453

6. Arah O, Ogbu U, Okeke C. Too poor to leave, too rich to stay: developmental aid global health correlates of physician migration to the United States, Canada, Australia, and the United Kingdom. Am J Public Health. 2008;98:148-54.

7. Séchet R, Vasilcu D. Les Mobilités des Médecins en Europe: Le cas des Mobilités Entre La Roumanie et la France. Sofia, BuLMarie: Genre, Médecins, Mobilités; 2012.

8. Vujicic M, Zurn P, Diallo K, Adams O, Poz MR. The role of wages in the migration of health care professionals from developing countries. Hum Resour Health. 2004:2:3.

9. Okeke EN. Do higher salaries lower physician migration? Health Policy Plan. 2014;29:603-14.

10. Canadian Institute for Health Information. Distribution and internal migration of Canada's physician workforce. Ottawa: Canadian Institute for Health Information; 2007.

11. Brasil. Lei $n^{\circ} 12.871$, de 22 de outubro de 2013 2013. Programa Mais Médicos. Diário Oficial da União. 23 Out 2013, Seção 1, página 1[Online]. Available at: http://www.planalto.gov.br/ccivil_03/_ato2011-2014/2013/lei/ 112871.htm. Accessed 22 May 2014.

12. Oliveira FP, Vanni T, Pinto HA, et al. Mais médicos: um programa brasileiro em uma perspectiva Internacional. Interface - Comunicação, Saúde, Educação. 2015;19:623-34.

13. Póvoa L, Andrade M. Distribuição geográfica dos médicos no Brasil: uma análise a partir de um modelo de escolha locacional. Cadernos de Saúde Pública. 2006;22:1555-64.

14. Pinto LDS, Machado M. Médicos migrantes e a formação profissional: um retrato brasileiro. Revista Brasileira de Educação Médica. 2000;24:53-64

15. Scheffer M, Biancarelli A, Cassenote A, Demografia Médica no Brasil. 2015. Conselho Regional de Medicina do Estado de São Paulo e Conselho Federal de Medicina, 284 [Online]. Available at: http://www.usp.br/agen/wpcontent/uploads/DemografiaMedica30nov2015.pdf. [Accessed 20 Mar 2016].

16. Instituto Brasileiro de Geografia e Estatística. 2014. Estimativas populacionais para os municípios brasileiros em 01.07.2014 [Online]. Available at: https://ww2.ibge.gov.br/home/estatistica/populacao/ estimativa2014/estimativa_dou.shtm.

17. Conselho Federal de Medicina. 2017. CFM. Estatística[Online]. Available at: http://portal.cfm.org.br/index.php?option=com_estatistica. [Accessed 15 Dec 2017]

18. Instituto Brasileiro de Geografia e Estatística. 2017. IBGE. População [Online]. Available at: http://www.ibge.gov.br/apps/populacao/projecao/index.html. [Accessed 15 Dec 2017].

19. Scheffer MC, Poz MR. The privatization of medical education in Brazil: trends and challenges. Hum Resour Health. 2015;13:96.

20. OCDE, Simoens S, Hurst J. The supply of physician services in OECD countries. OECD health working papers, no. 21. Paris: OCDE; 2006

21. Scheffer MC, Cassenote AJF. A feminização da medicina no Brasil. Revista Bioética. 2013;21:268-77.

22. Willis-Shattuck M, Bidwell P, Thomas S, Wyness L, Blaauw D, Ditlopo P. Motivation and retention of healthworkers in developing countries: a systematic review. BMC Health Serv Res. 2008;8:247.
23. El Koussa M, Atun R, Bowser D, Kruk ME. Factors influencing physicians' choice of workplace: systematic review of drivers of attrition and policy interventions to address them. J Glob Health. 2016;6(2):020403.

24. McGrail MR, Humphreys JS. Geographical mobility of general practitioners in rural Australia. Med J Aust. 2015;203(2):92-6.

25. McGrail MR, Wingrove PM, Petterson SM, Bazemore AW. Mobility of US Rura Primary Care Physicians during 2000-2014. Ann Fam Med. 2017;15(4):322-8. https://doi.org/10.1370/afm.2096.

26. Mejia A. Migration of physicians and nurses: a world wide picture. Int. J. Epidemiol. 1978;7:207-15.

27. Bach S. Migration patterns of physicians and nurses: still the same story? Bull World Health Organ. 2004;82:624-5.

28. Forcier MB, Simoens S, Giuffrida A. Impact, regulation and health policy implications of physician migration in OECD countries. Hum Resour Health. 2004;2:12.

29. Canadian Institute for Health Information (CIHI). 2011. Supply, distribution and migration of Canadian physicians [online]. Available at: https://secure. cihi.ca/estore/productSeries.htm?pc=PCC34.

30. OECD Health Policy Studies. The looming crisis in the health workforce: how can OECD countries respond? [online]. Geneva: OECD; 2012. Available at: http://www.oecd.org/els/healthpoliciesanddata/41509461.pdf. Accessed 17 Dec 2012

Ready to submit your research? Choose BMC and benefit from

- fast, convenient online submission

- thorough peer review by experienced researchers in your field

- rapid publication on acceptance

- support for research data, including large and complex data types

- gold Open Access which fosters wider collaboration and increased citations

- maximum visibility for your research: over $100 \mathrm{M}$ website views per year

At BMC, research is always in progress.

Learn more biomedcentral.com/submissions 